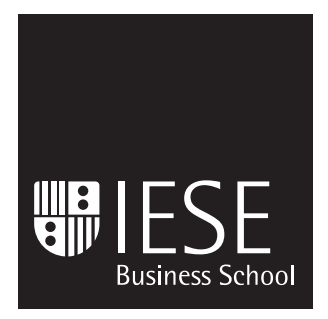

CIIF

Working Paper

WP no 689

University of Navarra

April, 2007

\title{
THE REACTION BY INDUSTRY INSIDERS TO M\&As IN THE EUROPEAN FINANCIAL INDUSTRY
}

\author{
José Manuel Campa \\ Ignacio Hernando
}

IESE Business School - University of Navarra

Avda. Pearson, 21 - 08034 Barcelona, Spain. Tel.: (+34) 932534200 Fax: (+34) 932534343

Camino del Cerro del Águila, 3 (Ctra. de Castilla, km 5,180) - 28023 Madrid, Spain. Tel.: (+34) 913570809 Fax: (+34) 913572913

Copyright ${ }^{\odot} 2007$ IESE Business School. 
The CIIF, International Center for Financial Research, is an interdisciplinary center with an international outlook and a focus on teaching and research in finance. It was created at the beginning of 1992 to channel the financial research interests of a multidisciplinary group of professors at IESE Business School and has established itself as a nucleus of study within the School's activities.

Ten years on, our chief objectives remain the same:

- Find answers to the questions that confront the owners and managers of finance companies and the financial directors of all kinds of companies in the performance of their duties

- Develop new tools for financial management

- Study in depth the changes that occur in the market and their effects on the financial dimension of business activity

All of these activities are programmed and carried out with the support of our sponsoring companies. Apart from providing vital financial assistance, our sponsors also help to define the Center's research projects, ensuring their practical relevance.

The companies in question, to which we reiterate our thanks, are:

Aena, A.T. Kearney, Caja Madrid, Fundación Ramón Areces, Grupo Endesa, Royal Bank of Scotland and Unión Fenosa.

http://www.iese.edu/ciif/ 


\title{
THE REACTION BY INDUSTRY INSIDERS TO M\&As IN THE EUROPEAN FINANCIAL INDUSTRY
}

\author{
José Manuel Campa* \\ Ignacio Hernando**
}

\begin{abstract}
This paper looks at the reaction by industry insiders, industry analysts and competing firms to the announcement of M\&As that took place in the European Union financial industry in the period 1998-2006. Analysts covering firms involved in an M\&A transaction do not significantly alter their recommendation. This is consistent with the hypothesis that the transaction on average is "fairly priced" and that stock market prices reflect all relevant information on the assets. We also find that the correlation between excess returns for merging and competing firms is positive and, in some cases, significantly higher for domestic mergers than for international deals. This is consistent with the idea that domestic deals are more likely to have a negative impact on industry competition.
\end{abstract}

\footnotetext{
* Professor of Financial Management, Grupo Santander chair in financial institutions, IESE

** Bank of Spain
}

Clasificación JEL: G20, G34

Keywords: Mergers and acquisitions; analysts' recommendations; rival firms. 


\section{THE REACTION BY INDUSTRY INSIDERS TO M\&As IN THE EUROPEAN FINANCIAL INDUSTRY}

\section{Introduction}

The integration of the financial industry in the European Union is at the forefront of the public policy debate. Integration of financial markets is perceived as an essential part of the process of real economic integration within European markets. The European financial industry has followed a cyclical pattern of M\&A activity during the last decade. M\&A activity was very intense during the late nineties and decreased considerably from 2001 to 2003, increasing its pace again in 2004 to the present. Interestingly, most transactions within the European Union have taken place among domestic firms. Moreover, international M\&As in the banking industry until recently had been carried out more often with banks from outside the euro-zone than with banks from different euro area countries (Hartmann et al., 2003). This pattern has shifted in the last two years. A few major international transactions, such as the successful purchases by Banco Santander of Abbey National Bank in the UK, by Unicredito of HVB in Germany, by ABN Amro of Antonvenetta and by BNP Paribas of BNL in Italy and the failed attempt by BBVA in Italy have increased interest in the pattern of concentration at the European level. At the same time, the mixed results in the attempts by BBVA and ABN Amro to acquire Italian banks, in a context of sharp opposition by the Italian banking establishment, ${ }^{1}$ have also highlighted how integration at the European level is still subject to considerable institutional and nationalist barriers (European Commission, 2005).

The underlying motives for engaging in an M\&A transaction concern the efficiency gains reflected in lower costs and higher profits involved in the merger, the geographical diversification generated from the merger, the improvement in the competitive position, and the increase in the ability to generate value for the consumer by product cross-sales. In addition, pre-emption motives may be behind some mergers that appear to reduce profits (Stennek,

NOTE: We wish to thank María Oleaga and Isabel Paúl for their very helpful assistance and Jorge Martínez Pagés, Victor González, José Manuel Marqués, Jörg Rocholl, an anonymous referee, and seminar participants at the Bank of Spain, the XIV Foro de Finanzas, the FUNCAS Workshop on European Banking and the $8^{\text {th }}$ Conference of the ECBCFS Research Network on "Financial Integration and Stability in Europe" for their comments. The views expressed in this paper are those of the authors and do not necessarily reflects the views of the Bank of Spain.

${ }^{1}$ This opposition is not only circumscribed to the banking establishment. Thus, for instance, the recent approval by the Bank of Italy of the acquisition of BNL by BNP has also generated criticisms among political parties and consumer associations. 
2006). ${ }^{2}$ Studies of merger activity point to efficiency gains as the major source of value creation, while the net increase in revenue generated from the merger tends to be small (Houston and Ryngaert, 1994). However, it is difficult to find strong statistical evidence for the existence of these efficiency gains. Studies looking at the source of value creation in M\&As in the European financial industry are inconclusive at best. In a study of value creation to shareholders upon announcement of an M\&A transaction Beitel and Schiereck (2001) report that returns to shareholders of the acquiring firm tend to be negative as the size of the acquiring bank increases. In a similar event study analysis of 54 M\&As deals in 13 European banking markets, Cybo-Ottone and Murgia (2000) find a positive and significant increase in stock market value at the time of the deal announcement except in the subsample of crossborder deals. ${ }^{3}$ Campa and Hernando (2006) find a post-merger improvement in the profitability performance of acquired banks relative to the industry but this performance improvement only appears two years after completion of the transaction. ${ }^{4}$

This lack of performance in M\&A transactions in the financial industry has raised concerns about the competitive outcome that this concentration may imply. Concentration in the financial industry in many European countries has significantly increased. The share of total banking assets held by the five largest institutions (the C5 concentration ratio) in small countries such as Belgium, Finland and the Netherlands was above 80\% in 2005. Concentration has also increased in all major national markets of the Euro area over the period 1997-2005. In Spain, the C5 ratio increased by 10 percentage points (from 32\% to 42\%); in France, by 14 p.p. (from 40\% to 54\%); in Germany, by 5 p.p. (from 17\% to 22\%) and in Italy, by 2 p.p. (from 25\% to $27 \%$ ). Despite this increase in concentration at the national level, concentration in the Euro area as a single market is markedly lower. ${ }^{5}$ Bikker and Wesseling (2003) report that the C5 concentration ratio defined for the Euro area increased by 4 p.p., from 12\% in 1996 to $16 \%$ in 2001. Nevertheless, this increase in concentration ratios does not necessarily reflect lower competition. In fact, the rising trend in the share of foreign credit institutions in local markets, the slight contraction in net interest margins and the improvement in efficiency ratios indicate a strengthening of competition in European banking markets (Allen et al., 2005). These developments are more likely caused by the development of parallel trends affecting competition beyond domestic consolidation such as the implementation of new technologies and regulatory changes in the industry.

In this paper we assess the magnitude of value creation associated with merger deals and further analyze the underlying motives for recent mergers in the European financial sector. In particular, we go beyond shareholder value creation for the firms involved and evaluate value creation in the industry. We use an indirect approach: rather than focusing on the reaction of the prices of the merging firms upon the deal announcement, we look at the response of other

\footnotetext{
${ }^{2}$ The underlying idea is that in some cases the relevant alternative for comparing the potential benefits of a merger deal from the acquirer's point of view is an alliance of their competitors rather than the absence of any merger process. In other words, when certain developments increase the likelihood of merger processes in a given industry, being an insider might reduce profits less than being an outsider.

${ }^{3}$ Similarly, Campa and Hernando (2004) show that international mergers within Europe destroy shareholder value, especially in regulated industries.

${ }^{4}$ More detailed overviews of the developments in the M\&A activity in the EU financial sector may be found in ECB (2000, 2004a, 2004b and 2005), Cabral et al. (2002), Hartmann et al. (2003) and Bikker and Wesseling (2003).

${ }^{5}$ See ECB (2004a) for a detailed overview of recent developments on EU banking structure and Gual (2004) and Pérez, Salas and Saurina (2005) for an assessment of the integration process of EU banking markets.
} 
participants in the market. We first look at the changes in recommendations by industry analysts and then at the stock price reaction of the rival companies. We follow an event study methodology based on stock prices' reaction to merger announcements. This strategy complements other approaches used in the industrial organization literature based on the analysis of the changes in balance sheets, costs or profits resulting from merger processes. The event study methodology is well suited to avoid the problem of holding constant other factors that are usually present in other ex-post studies of merger effects (Caves, 1989).

One of the weaknesses often highlighted for event study results is that stock market prices over short windows may not be a good reflection of the full value of the merger. This criticism has two variants. Skeptics of the efficiency of financial markets view event studies focus on shortterm windows around announcement as a poor reflection of the true value added for the firms involved in these complex transactions. ${ }^{6}$ A second line of criticism does not focus on the methodology but rather on the narrow definition of value creation. Event studies, with their focus on shareholder value creation for the firms involved, are only a partial measure of the economic value created from a transaction. In particular, they do not take into account the resulting value created for consumers through increased competition in the industry. Therefore, the results from this type of analysis are likely to provide poor guidance for the evaluation of the attractiveness of these transactions.

We tackle the first criticism in two ways. First, we look at a longer time horizon, one year, to evaluate the stock market performance and how the merger has affected it. However, we go beyond this and study the changes in perception by industry analysts of the expected returns to shareholders after the announcement. Changes in analyst recommendations have been shown to be predictors of future excess performance. Given the consensus that market prices do not reflect the expected returns from the merger, analysts as informed agents should change their recommendations on these stocks. We find little evidence in this regard. Analysts do not alter their recommendations in a manner significantly different after the merger announcement than in other periods in which there is no similar news. This evidence suggests that stock market prices react fairly fast to all the relevant information for expected returns from the merger announcement.

The second part of the paper addresses the second criticism. We analyze whether the increase in concentration arising from the domestic consolidation process that has taken place has resulted in a significant change in the competitive environment in the financial industry. We evaluate the stock market reaction by competing firms around the announcement of a transaction. There is a long history starting with Eckbo (1983) and Stillman (1983) of looking at the reaction of the stock market price of competing firms to evaluate the likely gains from a merger. ${ }^{7}$ The key point in this literature is that when a merger is expected to decrease competition, industry margins are expected to increase and therefore, returns to shareholders of all the firms in the industry should also increase. However, when the merger is expected to foster competition, its announcement should cause a fall in the stock market price of competing firms. We follow this literature and evaluate the reaction by competing firm stocks around a merger announcement. We generally find a positive correlation between the excess returns of the merging firms and

\footnotetext{
${ }^{6}$ Campa and Hernando (2006) evaluate the changes in the operating performance of the banks involved in these transactions up to five years after the merger. The evidence indicates that the return on equity of the target firm does not start to increase until two years after completion of the transaction.

${ }^{7}$ See also Eckbo (1992) and Singal (1996).
} 
those of their competitors, which indicates that market power might increase as a result of these transactions.

The rest of the paper is organized as follows. Section 2 describes the sample of M\&A deals used in the event studies, and the details on the data from competing firms and analysts' coverage. Section 3 presents the results on the reaction of analysts' recommendations upon announcement. Section 4 presents the results of the analysis on excess returns of competing firms around announcements. Section 5 concludes the paper.

\section{Sample of M\&A Transactions}

To evaluate the reactions by industry insiders upon the announcement of an M\&A transaction, we focus on the events around the announcement of an M\&A transaction in the European Union $^{8}$ (EU) during the period 1998-2006. The selected sample includes M\&A transactions announced within the EU in which both firms involved in the transaction were financial firms (within SIC 60 to 67) and both were publicly traded companies. We excluded those deals in which either the target or the acquirer was a real estate company and those transactions in which the buyer already owned 50\% of the targeted company. We also decided to drop from the sample some outliers in terms of the excess returns of either the acquirer or the target firm. ${ }^{9}$ This gave us a final sample of 218 transactions. Table 1 provides some information on the sample composition. The vast majority of these transactions (159) were domestic transactions, i.e. involved two institutions from the same country. The sample varied significantly by segment within the financial industry. Over half of the sample (119 acquirers) included depository institutions within the European Union, followed by holding companies and other financial firms (45 acquirers) and by insurance companies (34). We also present results for a sample of 125 banking deals, i.e. transactions in which both institutions involved are depositary institutions. $^{10}$

We performed event studies around the announcement date of the merger ( $t$ ). We obtained the cumulative excess returns to the target and acquirer through three distinct periods around this date: pre-announcement period ([t-90, t-1]), announcement period $([t-1, t+1])$ and postannouncement period $([t-1, t+30])$. We also looked at the cumulative excess return to the acquirer a year after the merger announcement $([t-1, t+360])$. Cumulative excess returns are defined as the difference between the total shareholder return of the company involved during the event window minus the return to the national stock market index during that period. ${ }^{11}$ This

\footnotetext{
8 Throughout this paper, we have considered the European Union of 15 countries, before enlargement on 1 May 2004.

${ }^{9}$ More precisely, we drop a deal from the sample if the excess returns of either the target or the acquirer computed for different windows around the announcement date $(t)$ exceed 100\%. In particular, we consider the following windows: [t-90, t-1], [t-1, t+1], and [t-1, t+30].

${ }^{10}$ For this purpose, we use a broad definition of banking institution including: depository institutions (SIC 60), nondepository credit institutions (SIC 61), security and commodity brokers and services (SIC 62), and holding companies and investment offices (SIC 671 and 672).

${ }^{11}$ We also calculated excess returns as the difference between actual returns and a measure of expected returns calculated using the CAPM during the six months prior to the event window; the results were qualitatively similar. Additionally, we also used the financial industry index as the relevant market index. This also had no substantial implications for the results. See Campa and Hernando (2006) for details.
} 
sample and the information on excess returns comprise our reference sample for competing firms and analyst coverage.

Table 2 reports summary statistics on excess returns to targets and acquirers. Target companies experienced a positive excess return around the announcement of the merger. This excess return was on average 3.38\% from the day prior to the merger announcement to the day after the announcement. An asymmetry is observed in the computed excess returns before and after the announcement. There are significant run-up returns. Excess returns over the period [t90, t-1] are positive. No additional excess return is observed beyond the first day after the announcement. The average excess return in the window [t-1, t+30] was $1.73 \%$, that is, substantially lower than the average excess return observed over the shorter window $[t-1, t+1]$. Moreover, long-run excess returns are not significant. The distribution of excess returns is quite asymmetric and median excess returns tend to be smaller. There is a higher proportion of target firms that experience positive excess returns; depending on the window, this proportion fluctuates between $51 \%$ and $60 \%$ of all targets.

For acquirers, the distribution of excess returns around announcement is substantially different. Average excess returns are negative, with the exception of the pre-announcement window, and amount to about $-1 \%$. There does not appear to be any significant excess return during the runup period prior to announcement. Long-run returns are also negative although not significant. Excess returns to acquirers experienced a wide scatter around the average number. The median excess return is very close to zero in most cases. In fact, the percentage of acquirers that experienced positive excess returns is around 50\% for all windows.

We compare excess returns in terms of the geographical scope of the merger and the size of the deal, measured by the joint market capitalization of the merging companies. Value creation is expected to be lower in cross-border deals. Such deals usually offer lower potential synergies than domestic deals and are less likely to affect industry competition. Cross-country differences in safety net characteristics that result in different risk-taking activities could also give rise to some premia for institutions moving to countries with a different degree of safety net (Hovakimian et al., 2003). We find that excess returns to targets are substantially lower in cross-border mergers than in domestic deals, especially when measured by median values. The magnitude of this difference is especially high over the pre-announcement window and over the long-run post-announcement window. Average and median excess returns to targets are higher than those to acquirers in domestic mergers. The difference in excess returns for acquirers between domestic and international deals depends on the window considered.

In terms of deal size, small (large) mergers include those transactions in the lower (upper) quartile of the distribution. The differences by size are quite striking, especially in the long run. Short-run excess returns to targets are somewhat higher in small deals while the opposite is true for acquirers. The differences are much larger over the long-run window. Small deals had an average (median) excess return for shareholders of the target firm of $-1 \%(-7 \%)$ and an average (median) excess return of $-11 \%(-2 \%)$ for the shareholders of the acquirer. In contrast, excess returns in large deals were substantially higher both for targets and acquirers: average (median) excess returns were $2 \%(4 \%)$ for shareholders of the target firms and $6 \%(7 \%)$ for those of the acquiring companies. These results are consistent with Kane (2000) who suggests that large deals generate high excess returns because the resulting institution may benefit from being "too big to discipline adequately". 


\section{Analysts' Recommendations}

Information from analysts' recommendations has been used often as a source of information for predicting returns. There is consensus in the literature that the level of analysts' recommendations, although it may help in predicting future returns, does not result in strategies that could be implemented to generate excess returns. Barber, Lehavy, McNichols and Trueman (2001) show in a large sample of over 360,000 analysts' recommendations that buying a portfolio of firms with a buy recommendation resulted in a higher return than buying a portfolio of firms with a sell recommendation. However, the strategy of shorting the latter portfolio to buy the portfolio of highly recommended firms did not result in positive excess returns after transaction costs. While investment strategies based on analyst consensus do not generate excess returns, positive excess returns are observed when the strategy picks portfolios based on changes in recommendations by analysts. Along this line, Stickel (1995) and Womack (1996) have documented that positive (negative) changes in analysts' recommendations are accompanied by positive (negative) returns at the time of their release. Moreover, Boni and Womack (2006) show that changes by analysts in their recommendations (upgrades or downgrades) are especially useful in predicting relative performance of a firm within its industry. However, analyst recommendations are not good predictors of future relative returns across industries. Overall, the literature suggest that changes in analysts' recommendations appear to be a predictor of future returns, after controlling for a number of relevant stock characteristics.

Analysts often change their recommendations upon the announcement of a major event affecting the firm. M\&A transactions are one clear candidate for such an event that can produce a drastic variation in the business perspective of the firms involved and the expected return on their respective stock. We would therefore expect that analysts' reactions to the announcement of a merger may provide useful information on the value of the merger to investors.

We have compiled a database on analysts' recommendations of the companies involved in M\&As deals. The database summarizes for every firm, every month, the ratings by all analysts covering the firm in a scale of one to five. Each observation corresponds to analysts' recommendations for a given company and month (the Thursday before the third Friday of every month). The database covers the period 1997-2006. We were able to find information for 159 acquirers and 140 targets of the 218 transactions in our sample. For each observation, we have information on the number of analysts that follow the stock, the mean, median and standard deviation of the company recommendation and the number of analysts that have upgraded/downgraded the firm relative to the previous month. ${ }^{12}$ The ratings are based on the firm's stock performance expected by the analysts. A value of one represents the highest expected performance while five represents the lowest. ${ }^{13}$

It is important to stress that these data do not measure the companies' quality in absolute terms but in relation to their market price. Thus, a good recommendation means that the analyst considers that the company is undervalued in the market and therefore he/she recommends buying this share at the current price. Similarly, a change in the recommendation around the announcement date can be interpreted as the analyst's perception of how the deal is going to

\footnotetext{
${ }^{12}$ For the deals announced over the period 2003-2006, we only know the average number of analysts following the stock and the average score.

${ }^{13}$ More precisely, the set of recommendations, each with an assigned numeric value, is as follows: (1) strong buy, (2) buy, (3) hold, (4) underperform, and (5) sell.
} 
affect the company's performance. Nevertheless, changes in recommendations have to be interpreted with caution as they are probably accompanied by changes in share prices.

Table 3 reports the evidence on analysts' recommendations the month prior to the announcement of the deal. Three conclusions can be drawn from this evidence. First, the average recommendation for acquirers is slightly better than that for targets, although the difference is only marginally significant. This difference between the average recommendations of targets and acquirers is mainly due to the ratings of companies involved in cross-border deals. Second, acquirers in international mergers had better ratings than their targets in over $60 \%$ of the cases. In contrast, the average recommendation of the two firms in domestic transactions is quite similar. Third, the average recommendation for targets is not significantly different around the merger announcement from what is observed in non-announcement periods. The last three rows of Table 3 report the mean and the median of average recommendations for the target and acquirer firms in the months in which they were not involved in a transaction. ${ }^{14}$ The mean (median) of average recommendations for target firms in non-announcement periods was 2.62 (2.62) while in the periods around which the takeover took place, it was 2.59 (2.65). It cannot be concluded from this evidence that target firms get acquired when analysts consider that the firm is undervalued.

Focusing only on the subset of banking deals, there is no significant difference in the average score between targets and acquirers. This is explained by slightly better recommendations for targets in domestic deals and significantly better ratings for acquirers in cross-border deals. Moreover, average recommendations for targets in domestic deals are significantly better than recommendations during the periods in which no transaction takes place. The opposite is true in cross-border deals.

As discussed above, changes in analyst recommendations are better in predicting excess returns. Therefore, a comparison of changes in recommendations around the announcement dates is potentially more informative than the analysis of the average recommendations performed so far.

Table 4 reports statistics on changes in recommendations. ${ }^{15}$ We look at the last recommendation prior to the announcement of the transaction and focus on the number of analysts covering the stock who have changed their recommendation. We do the same thing for the first set of analysts' recommendations after the announcement of the merger. Finally, to capture any possible delays in analysts' recommendations, we also report the same statistics for the cumulative information up to four months after the announcement. We split the results in four groups: observations where no analyst has changed his/her assessment, observations where all analysts changing their assessment indicate a downgrade, observations where all analysts changing their assessment indicate an upgrade and, finally, observations where there are analysts changing their recommendations in opposite directions. In the last column of the table, we provide the analog values for those variables during the 1997 to 2003 period for the nonannouncement periods. This last column provides a benchmark for comparing the significance of these changes in recommendations. The distribution of observations just before the merger,

\footnotetext{
14 Non-announcement periods include all observations preceding the last three recommendations before the announcement and all observations following the first four recommendations after the announcement.

${ }^{15}$ Results reported in this table are obtained from the sample of deals announced over the period 1998-2003, as the information on changes in recommendations is not available for the most recent transactions.
} 
based on the existence of changes in recommendations and the sign of these changes, is very similar to the distribution of observations in non-announcement periods. In these nonannouncement periods, the number of companies/periods pairs that display a change in a recommendation is approximately one third. This number breaks down to around $12 \%$ that display uniform downgrades, $11 \%$ that show uniform upgrades and 10\% that display changes in recommendations in both directions. ${ }^{16}$ Interestingly, in both the upgrades only and the downgrades only subsamples, the percentages of analysts changing their recommendations is just around 10\%. Moreover, the fraction of observations where more than 20\% (or 50\%) of analysts change recommendation is very small.

The fraction of observations without changes in the period just prior to the announcement is smaller for acquirers. However, these firms experience a higher fraction of uniform upgrading. In the case of targets, the fraction of observations with changes in recommendations of the opposite sign is lower. Moreover, for those observations with uniform downgrading the average fraction of analysts changing their recommendations (22\%) is higher than in the case of nonannouncement observations (around 10\%).

More surprisingly, the distribution of changes in recommendations after the announcement, and the sign of these changes, is again very similar to the distribution of observations in nonannouncement periods. The fraction of target observations with changes in recommendations of the opposite sign is lower, especially for the mergers involving banks. There is a higher fraction of uniform upgrading and a lower fraction of uniform downgrading among acquiring firms but, in this case, the average fraction of analysts changing their recommendations is higher.

Finally, looking at the changes in recommendations over the first four months after the announcement of the deal, we observe that the proportion of observations without changes in recommendations is smaller. This is not surprising given the longer length of the time interval. However, the fraction of observations with changes in recommendations of the opposite sign is higher, suggesting that there is no consensus among analysts even four months after announcement of the transaction.

To summarize, changes in recommendations on firms involved in merger deals are not exceptionally frequent. There are no uniform patterns in changes in recommendations across analysts. The fraction of average downgrades and upgrades around announcement dates is not substantially different from those observed in non-announcement periods. Overall, we interpret this "lack of reaction" by analysts as being consistent with the hypothesis that the transaction on average is "fairly priced" and that stock market prices after the announcement reflect all relevant information on the assets. Finally, a note of caution. Analysts affiliated with companies acting as financial adviser to the merging firms in each transaction cannot issue recommendations on the merging companies during the merging process. Considering that these analysts have more information on the likely outcome of the merger process, the evidence presented here may be underestimating the impact on the performance expected by the analysts. ${ }^{17}$

\footnotetext{
${ }^{16}$ Similar figures are found when we restrict our analysis to the sample of completed banking deals.

${ }^{17}$ It would also be interesting to analyse whether local analysts, who a priori may have better information, are more likely to change their recommendations in reaction to a merger announcement. The idea that local analysts have better information is supported by Bae et al. (2005), who find that analysts resident in a country make more precise earnings forecasts for firms in that country than analysts who are not resident in that country, even after controlling for firm and analyst characteristics. See also Malloy (2005) for related evidence.
} 


\section{The Stock Market Reaction of Competing Firms}

The analysis of the stock market reaction of rival companies to merger announcements may be useful for identifying the underlying rationale for integration deals. The use of competitors' data to determine the ultimate impact on competition from the merger was pioneered by Eckbo (1983) and Stillman (1983). Value creation from M\&As arising from efficiency gains should result in a negative correlation between excess returns of the merging firms and those of their competitors. Efficiency enhancements by a competitor are likely to result in a more competitive environment, making it more difficult, at least in the short run, for existing firms to maintain their profitability. In contrast, as M\&As result in an increase in concentration and a decline in the intensity of competition, the stock of competing firms should react positively as the value to their shareholders will likely increase in the future. Moreover, as domestic deals are more likely to lead to industry consolidation and as a result affect market competition, we can expect, on average, higher excess returns to the shareholders of rival companies in domestic deals. By contrast, the entry of foreign banks, as a result of cross-border deals, may foster competition, inducing local banks to innovate and improve service quality. As Claessens, Demirgüç-Kunt and Huizinga (2001) show, foreign ownership of banks is usually negatively correlated with domestically owned banks' profitability and margins.

Focusing on the analysis of the stock market reaction of rival companies limits the evaluation of competition to only publicly-traded competitors. In some segments of the financial industry -such as retail banking- a substantial share of the market is controlled by non-quoted companies (i.e. savings banks or cooperative banks), particularly in certain countries. Therefore, in these cases our approach does not capture the competitive impact of the merger in a substantial fraction of competitors. It is also worth mentioning that in some countries, these non-quoted companies have important limitations on the changes allowed in their ownership structure. This poses an important obstacle to the integration of these market segments at the European level.

We define the set of competing firms as all the companies belonging to the same financial service industry ${ }^{18}$ listed in the same country as the target company. We assume that any impact on competition will likely take place in the market of the acquired company. For domestic mergers, this is not controversial since the relevant market is the same for the acquirer and target firms. This is not true for international mergers. Given the high level of concentration of European financial firms in their domestic markets, an international merger usually results in an increase in the geographical scope of the acquiring company. In this case, we assume that competition effects, if any, are likely to occur in the national market of the target. ${ }^{19}$

For each set of competing firms, we compute the excess return to shareholders around the same windows as we did for the firms involved in the M\&A transaction. ${ }^{20}$ This provides us with a

\footnotetext{
${ }^{18}$ For this purpose, we consider the following industry segments: Banks (81), Insurance (83), Life Assurance (84), Investment companies (85), Speciality and other finance (87). In brackets, we specify the FTSE/HANG SENG indexes' reference codes.

${ }^{19}$ Note that this assumption will be more adequate in those industries that are geographically segmented like retail banking. However, the assumption is less satisfactory in those industry segments that are more integrated or where the cross-border service provision is more relevant.

${ }^{20}$ Excess returns for competing firms are computed as the difference between the stock market return of each firm minus the return of the national stock market index during the same period.
} 
sample of excess returns of competing firms for every transaction. Summary statistics for the average of these excess returns are reported in the last three columns of Table 2. Overall, we find that average and median excess returns are predominantly positive although close to zero. Interestingly, we find that average and median excess returns for the announcement window are small but significantly positive, both for the total sample and for domestic deals. These results might indicate that merger deals have led to a reduction in the level of competition. We also find that long-run average excess returns for competing firms are positive, although not statistically significant, given the wide scatter across companies. Consistent with the hypothesis of an anticompetitive rationale for merger deals, we find that, with the exception of the preannouncement window, domestic deals tend to generate higher excess returns for rival companies than cross-border deals, the difference being particularly sizeable for the long-run window. In contrast, the comparison of rivals' excess returns in terms of the size of the deals does not offer conclusive results.

Positive excess returns to competing firms around merger announcements are also compatible with increases in the probability that these competing firms may themselves become targets of future M\&A deals. M\&A transactions are clustered over time, and we do find evidence in Table 2 of positive excess returns to targets prior to the announcement of a transaction. Under this explanation, investors, given the announcement of a transaction, would boost valuations of competing firms in the expectation of further transactions at higher prices. This explanation relies on a rationale for why further transactions would occur at higher prices. Under efficient markets, higher prices can only be supported by the expectation of higher future cash-flows for the firms involved. This is precisely the anticompetitive hypothesis being tested.

We also look at the fraction of competitors which display positive abnormal returns over different windows around merger deal announcements. According to the hypothesis of increases in market power, we should expect a high fraction of companies displaying positive excess returns and this fraction should be lower for cross-border deals.

Results along this line are reported in Table 5 and the evidence is far from conclusive. First, around one half of the competing firms displayed positive excess returns over the different horizons. This share is somewhat higher when considering the long-run window, suggesting that the perception of market power gains associated to the transaction is higher as the observation window gets larger. Second, there are no significant differences between domestic and cross-border deals in the fraction of rivals with positive abnormal returns. If anything, this fraction is higher in domestic transactions around the announcement window, favoring the hypothesis of increases in market power. A final interesting feature arising from these results is the absence of a uniform reaction of competing firms to merger announcements. The fraction of deals in which at least $75 \%$ of the rivals display positive abnormal returns is low for all windows.

According to the hypothesis of market power gains, the partial correlation between the excess returns of merging firms and those of their competitors should also be positive. To test this hypothesis, we regress the estimated excess returns of the merging firms over the average excess return of their competitors. Our goal in doing this regression is not to establish a causal relationship between excess returns of target and competing firms. The purpose is exclusively to evaluate to what extent the reported correlation is robust to the inclusion of additional controls. We also included a number of other control variables, including a set of year dummies, a dummy for the geographical scope (DOMESTIC), the relative size of the merging firms (RSIZE) and dummies for the top and bottom quartile of absolute size of the deal (LARGEDEAL and SMALLDEAL). Results are reported in Table 6. 
We generally find a positive correlation between target excess returns and those of their competitors, although it is not significant for the window $[t-1, t+1]$. Similarly, we also find a positive correlation between acquirer excess returns and those of their competitors, although it is again not significant for the announcement window [t-1, t+1]. This evidence points towards a positive correlation between merging firms' and rivals' returns around the announcement period. This evidence would be consistent with the hypothesis that market power increases as a result of these transactions.

We would also expect this effect to be more prevalent for domestic than for international transactions. We test this hypothesis by including an interaction term between the average competitors' excess return and the dummy for domestic deals (DOM_RIV). The evidence is only weakly favorable to this hypothesis. Both for targets and acquirers, the interaction term is predominantly positive and it is significant over the long-run window, which implies a higher correlation between merging firms' and rivals' returns in domestic mergers. For the long-run window [t-1, t+360], the correlation between target firms' and rivals' excess returns is positive and significant for domestic mergers while it is not significant for cross-border mergers. ${ }^{21}$

Finally, it is worth mentioning that the observed positive correlation between the excess returns of target and competing firms may be driven by common factors affecting the financial industries involved and not related to the transaction. Recall that excess returns are computed relative to market returns in each country. The presence of common industry trends would result in the observed positive correlation. This is more likely to occur for the larger windows considered and may explain the positive correlation for the longer windows in Table 6 . By construction, this effect is less likely in the shorter windows, where we still find the positive correlation. We view this evidence jointly with the significant positive mean excess returns for competitors around announcement reported earlier as supportive of the impact that the announcement of these transactions has on expected returns to rivals.

\section{Conclusions}

This paper has looked at the reaction by industry insiders, industry analysts and competing firms to the announcement of M\&As that took place in the European Union financial industry in the period 1998-2006. The view that changes in stock market prices around the announcement of an M\&A deal are a fair reflection of the full value of the merger is a key assumption in event studies on the value creation of merger processes. We evaluate the changes in recommendations by industry analysts as an alternative measure of the expected returns generated from the merger.

Our results indicate that analysts covering firms involved in an M\&A transaction do not significantly alter their recommendation. Although acquiring firms tend to have a slightly better recommendation by analysts, their mean recommendation does not change around the announcement of an M\&A transaction. Target firms have analysts recommendations similar to the average firm in the industry and these recommendations are also not significantly altered

\footnotetext{
${ }^{21}$ We would also expect the positive correlation between excess returns of merging and competing firms to be more relevant in larger deals, since larger deals are more likely to have an impact on industry competition. However, the interaction between the average competitors' excess return and the deal size turned out to be not significant for all windows.
} 
around the announcement of a transaction. This lack of reaction by analysts is consistent with the hypothesis that the transaction on average is "fairly priced" and that stock market prices after the announcement reflect all relevant information on the assets.

The paper also analyses the stock market reaction of competing firms around a merger announcement. This is an empirical approach that has often been used to assess the transaction's likely impact on competition. By looking at the rivals' stock market reaction, we pursue a further analysis of the underlying motives for engaging in an M\&A process. We find a positive correlation between excess returns of the merging firms and those of their competitors, consistent with the idea that market power might have increased as a result of these transactions. Moreover, we also find evidence that returns to competing firms upon announcement differ between domestic and international mergers. The correlation between long-run excess returns for acquirers and competing firms is positive for domestic mergers and significantly higher than for international mergers. This is consistent with the hypothesis that domestic mergers are more likely to decrease industry competition. 


\section{References}

Allen, F., L. Bartiloro y 0. Kowalewski (2005), “The financial system of the EU 25," Wharton School, University of Pennsylvania, mimeo.

Bae, Kee-Hong, René M. Stulz, and Phil Tan (2005), "Do local analysts know more? A crosscountry study of the performance of local analysts and foreign analysts," NBER Working Paper No. 11697.

Barber, Brad, Reuven Lehavy, Maureen McNichols, and Brett Trueman (2001), "Can investors profit from the prophets? Security analyst recommendations and stock returns," Journal of Finance, 56, pp. 531-563.

Beitel, P. and D. Schiereck (2001), "Value Creation at the ongoing consolidation of the European Banking Market," Institute for Mergers and Acquisitions, working paper 05/01.

Bikker, J. and S. Wesseling (2003), "Intermediation, integration and internasionalisation: a survey on banking in Europe,” De Nederlansche Bank, Occasional Studies, Nr. 3.

Boni, Leslie and Kent Womack (2003), “Analysts, Industries, and Price Momentum?,” Journal of Financial and Quantitative Analysis, 41, (1), pp. 85-109.

Cabral, I., F. Dierick, and J. Vesala (2002), "Banking integration in the euro area," ECB Occasional Paper Series No. 6.

Campa, J. M. and I. Hernando (2004), "Shareholder value creation in European M\&As," European Financial Management, 10, (1), pp. 47-81.

Campa, J. M. and I. Hernando (2006), "M\&A Performance in the European Financial Industry," Journal of Banking and Finance, 30, (12), December, pp. 3367-3392.

Caves, R. (1989), "Mergers, takeovers, and economic efficiency," International Journal of Industrial Organization, 7 (1), pp. 151-174.

Claessens, S., A. Demirgüç-Kunt and H. Huizinga (2001), "How does foreign entry affect domestic banking markets," Journal of Banking and Finance, 25 (5), pp. 891-911.

Cybo-0ttone, A. and M. Murgia (2000), "Mergers and shareholder wealth in European banking," Journal of Banking and Finance, 24, pp. 831-859.

Eckbo, Espen (1983), "Horizontal Mergers, Collusion and Stock Market Wealth," Journal of Financial Economics, 11, pp. 241-273.

Eckbo, Espen (1992), "Mergers and the Value of Antitrust Deterrence," The Journal of Finance, 47 (3), pp. 1005-1029.

European Central Bank (2000), "Mergers and Acquisitions involving the EU Banking Institutions: Facts and Implications,” European Central Bank, Frankfurt, December.

European Central Bank (2004a), "Report on EU banking structure," European Central Bank, Frankfurt, November.

European Central Bank (2004b), "Research Network on capital markets and financial integration in Europe," European Central Bank, Frankfurt, December. 
European Central Bank (2005), "EU banking structures," European Central Bank, Frankfurt, October.

European Commission (2005), "Cross-border consolidation in the EU financial sector," Commission Staff Working Document, SEC (2005) 1398.

Gual, J. (2004), “The integration of EU banking markets,” CEPR Discussion Paper No. 4212.

Hartmann, P., A. Maddaloni, and S. Manganelli (2003), "The euro area financial system: structure, integration and policy initiatives, Oxford Review of Economic Policy, 19, pp. 180-213.

Houston, J. and M. Ryngaert (1994), "The overall gains from large bank mergers," Journal of Banking and Finance, 18, pp. 1155-1176.

Hovakimian, A., E. Kane, and L. Laeven (2003), "How country and safety-net characteristics affect bank risk-shifting," Journal of Financial Services Research, 23, pp. 177-204.

Kane, E. (2000), "Incentives for banking Megamergers: what motives might regulators infer from event-study evidence?," Journal of Money, Credit and Banking, 32, august.

Lyon, J., B. Barber, and C.-L. Tsai (1999), "Improved methods for tests of long-run abnormal stock returns,” Journal of Finance, 54, pp. 165-201.

Malloy, Christopher J. (2005), “The geography of equity analysis," Journal of Finance, 60 (2), pp. 719-755.

Pérez, D., V. Salas, and J. Saurina (2005), “Banking integration in Europe,” Banco de España, Working Paper No. 0519.

Singal, Vijay (1996), "Airline Mergers and Competition: An Integration of Stock and Product Price Effects,” The Journal of Business, 69 (2), pp. 233-268.

Stennek, J. (2006), “A new perspective on mergers and acquisitions: Evidence explained, policies prescribed," CESifo Forum, spring, pp. 3-8.

Stickel, S. E. (1995), "The anatomy of performance of buy and sell recommendations," Financial Analysts Journal, 51, pp. 25-39.

Stillman, R. (1983), "Examining Antitrust policy towards horizontal mergers," Journal of Financial Economics, 11, pp. 225-240.

Womack, K. (1996), “Do brokerage analysts' recommendations have investment value?," Journal of Finance, 51, pp. 137-167. 


\section{Table 1}

Sample Description

Panel A. Breakdown by country

\section{Cleaned sample}

Targets Acquirers
Banking

Targets

Acquirers

Austria

Belgium

Denmark

Finland

France

Germany

Greece

Ireland

Italy

Luxembourg

Netherlands

Portugal

Spain

Sweden

UK
3

5

10

2

12

32

10

2

44

2

7

14

11

7

57

218

Acquir

4

7

7

1

11

37

7

2

41

1
8
10

10

11

11

60

218
1

53

$0 \quad 0$

$\begin{array}{ll}9 & 7\end{array}$

$18 \quad 21$

$7 \quad 5$

22

$2 \quad 0$

$3 \quad 4$

$12 \quad 7$

$8 \quad 11$

24

$22 \quad 25$

$125 \quad 125$
$31 \quad 31$

Panel B. Breakdown by sector

$\begin{array}{lcccc} & \text { Targets } & \text { Acquirers } & \text { Targets } & \text { Acquirers } \\ \text { Depository institutions } & 107 & 119 & 94 & 100 \\ \text { Nondepository credit institutions } & 4 & 1 & 4 & 0 \\ \text { Security, commodity brokers and services } & 25 & 19 & 18 & 16 \\ \text { Insurance carriers } & 26 & 32 & 0 & 0 \\ \text { Insurance agents, brokers and services } & 4 & 2 & 0 & 0 \\ \text { Holding and other investment office } & 52 & 45 & 9 & 9 \\ & 218 & 218 & 125 & 125\end{array}$

\section{Panel C. Information on analysts and rivals}

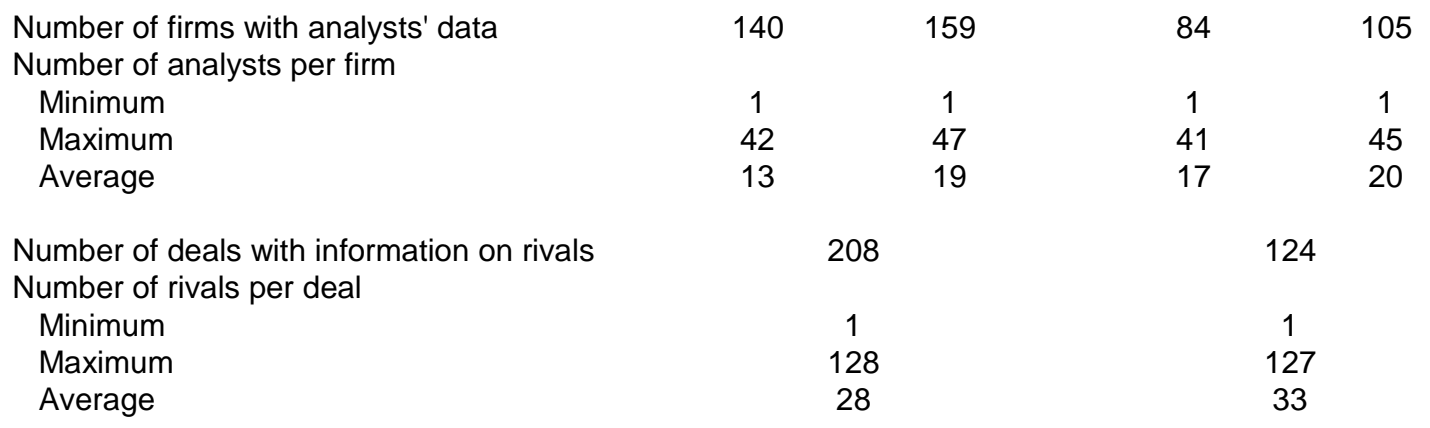

Rivals are those with the same FTAG4 code: Banks (81), Insurance (83), Life Assurance (84), Investment companies (85), Speciality and other finance (87). 


\section{Table 2}

\section{Cumulative Abnormal Returns}

Table 2. Cumulative Abnormal Returns

\begin{tabular}{ll} 
Targets \\
\hline Means (1) $\quad$ Medians (2) $\quad$ \% positive
\end{tabular}

\begin{tabular}{ll}
\multicolumn{3}{c}{ Acquirers } \\
\hline Means (1) $\quad$ Medians (2) $\quad \%$ positive
\end{tabular}

\begin{tabular}{l} 
Rivals \\
\hline Means (1) $\quad$ Medians (2) $\quad$ \% positive
\end{tabular}

All deals

$\begin{array}{cl}(\mathrm{t}-90, \mathrm{t}-1) & 3.74 \%^{* \star} \\ (\mathrm{t}-1, \mathrm{t}+1) & 3.38 \%^{* \star} \\ (\mathrm{t}-1, \mathrm{t}+30) & 1.73 \%^{*} \\ (\mathrm{t}-1, \mathrm{t}+360) & 1.32 \%\end{array}$

$\begin{array}{ll}5.24 \%{ }^{* *} & 60.1 \% \\ 0.78 \%{ }^{* *} & 58.3 \% \\ 0.61 \% & 52.3 \% \\ 0.18 \% & 50.5 \% \\ 218 & \end{array}$

Domestic deals

$\begin{array}{cl}(\mathrm{t}-90, \mathrm{t}-1) & 3.89 \%^{*} \\ (\mathrm{t}-1, \mathrm{t}+1) & 3.22 \%{ }^{* *} \\ (\mathrm{t}-1, \mathrm{t}+30) & 1.64 \% \\ (\mathrm{t}-1, \mathrm{t}+360) & 3.90 \% \\ \text { No. of deals }(3) & \end{array}$

$6.43 \%$ **
$0.84 \%$ **
$0.86 \%$
$1.95 \%$
159

\section{$62.3 \%$}

$59.7 \%$

$53.5 \%$
$52.4 \%$

$-0.54 \%$ *

$1.26 \%$

$-0.54 \%$ *

$1.28 \%$ **

$-0.08 \%$

$-1.46 \%$ *
$-1.86 \%$

$-0.56 \%$

$0.31 \%$

$48.6 \%$

$44.9 \%$

$0.58 \%$ *

218

$0.58 \%$

$0.28 \%$

$57.2 \%$

$0.45 \%$

$50.3 \%$

Cross-border deals

$\begin{array}{cc}(\mathrm{t}-90, \mathrm{t}-1) & 3.33 \%{ }^{*} \\ (\mathrm{t}-1, \mathrm{t}+1) & 3.82 \%{ }^{* *} \\ (\mathrm{t}-1, \mathrm{t}+30) & 1.95 \% \\ (\mathrm{t}-1, \mathrm{t}+360) & -5.33 \%\end{array}$

$$
\begin{array}{r}
2.64 \% \\
0.32 \% \\
-0.41 \% \\
-3.58 \% \\
\hline 59
\end{array}
$$

$54.2 \%$

$49.2 \%$
$45.6 \%$

$1.95 \%$
$-0.55 \%$

$-0.13 \%$

$-2.06 \%$

$1.12 \%$
$0.23 \%$
$-1.19 \%$
$0.76 \%$
159

$54.7 \%$

$51.6 \%$

$43.9 \%$

$-1.13 \%$
$0.83 \%$ **

$0.67 \%$

$0.26 \%$ **

$0.22 \%$

$48.4 \%$

$\begin{array}{cc}-1.78 \% & 0.76 \% \\ & 159\end{array}$

$51.0 \%$

$1.05 \%$

153

$52.3 \%$

$50.0 \%$

Small deals (4)

$\begin{array}{cc}(\mathrm{t}-90, \mathrm{t}-1) & 0.05 \% \\ (\mathrm{t}-1, \mathrm{t}+1) & 4.55 \% \\ (\mathrm{t}-1, \mathrm{t}+30) & 1.51 \% \\ (\mathrm{t}-1, \mathrm{t}+360) & -1.10 \% \\ \text { No. of deals (3) } & \end{array}$

$1.68 \%$
$0.90 \%$ **
$-0.41 \%$
$-7.33 \%$
49

$51.0 \%$

$67.3 \%$

$46.9 \%$

$2.26 \%$
$-1.46 \%$ **

$-2.38 \%$

$1.95 \%$ *

$-0.27 \%$

$-0.20 \%$

$-0.14 \%$

$62.7 \%$

$40.7 \%$

$47.5 \%$

$-0.11 \%$
$0.12 \%$

$0.08 \%$

$0.35 \%$

$0.45 \%$

$56.4 \%$

$-0.68 \%$

55

$52.7 \%$

$50.9 \%$

of deals (3)

49

$43.8 \%$

$11.34 \%$

$2.62 \%$

$-0.46 \%$

$-2.22 \%$

$-1.66 \%$

$40.8 \%$

$-1.33 \%$

$0.19 \%$

$-0.48 \%$

$0.55 \%$

$0.19 \%$
$-1.29 \%$

$-1.29 \%$
$-10.57 \%$ *

$52.1 \%$

49

48

\begin{tabular}{|c|c|c|c|c|c|c|c|c|c|}
\hline$(\mathrm{t}-90, \mathrm{t}-1)$ & $5.30 \%$ ** & $6.05 \%$ * & $63.3 \%$ & $2.23 \%$ & $1.56 \%$ & $59.2 \%$ & $-1.54 \%$ & $0.27 \%$ & $51.1 \%$ \\
\hline$(\mathrm{t}-1, \mathrm{t}+1)$ & $1.52 \%$ & $0.73 \%$ & $57.1 \%$ & $-0.97 \%$ ** & $-0.33 \%$ & $40.8 \%$ & $0.08 \%$ & $0.33 \%$ & $55.3 \%$ \\
\hline$(\mathrm{t}-1, \mathrm{t}+30)$ & $0.94 \%$ & $1.53 \%$ & $55.1 \%$ & $-0.77 \%$ & $-0.68 \%$ & $38.8 \%$ & $0.09 \%$ & $1.09 \%$ & $57.4 \%$ \\
\hline$(\mathrm{t}-1, \mathrm{t}+360)$ & $1.97 \%$ & $3.67 \%$ & $54.3 \%$ & $5.96 \%$ & $7.37 \%$ * & $66.0 \%$ & $2.65 \%$ & $5.26 \%$ & $56.8 \%$ \\
\hline vo. of deals (3) & & 49 & & & 49 & & & 47 & \\
\hline
\end{tabular}

$41.7 \%$

$36.2 \%$

Large deals (4)

(1) */* denote significance at the $10 \% / 5 \%$ level. Confidence intervals on the distribution of excess returns have been adjusted for skewness following the methods described in Lyon et al. (1999).

(2) ${ }^{* / *}$ denote significance at the $10 \% / 5 \%$ level.

(3) The number of deals is smaller for the long-run window as the excess return could not be computed for those deals announced at the end of the sample period.

(4) Small (large) deals are those included in the lower (upper) quartile of the distribution in terms of the size of the deal, measured by the joint market capitalization of the merging

companies. Joint market capitalization is only available for 196 deals. 


\section{Table 3}

Comparison of Recommendations Before Deal Announcements

\begin{tabular}{|c|c|c|c|c|}
\hline & \multicolumn{2}{|c|}{ Full sample } & \multicolumn{2}{|c|}{ Banking deals } \\
\hline & Target & Acquirer & Target & Acquirer \\
\hline \multicolumn{5}{|l|}{ All deals } \\
\hline Mean of average scores & 2.59 & 2.49 & 2.58 & 2.51 \\
\hline p-value (1) & 0.31 & 0.49 & 0.28 & 0.36 \\
\hline p-value (2) & \multicolumn{2}{|c|}{0.10} & \multicolumn{2}{|c|}{0.24} \\
\hline Median of average scores & 2.65 & 2.50 & 2.62 & 2.45 \\
\hline Number of observations & \multicolumn{2}{|c|}{124} & \multicolumn{2}{|c|}{80} \\
\hline \# with aver(T)>aver(A) & \multirow{2}{*}{\multicolumn{2}{|c|}{$\begin{array}{c}70 \\
5\end{array}$}} & \multicolumn{2}{|c|}{47} \\
\hline \# with aver $(\mathrm{T})=\operatorname{aver}(\mathrm{A})$ & & & & \\
\hline \# with aver $(\mathrm{T})<\operatorname{aver}(\mathrm{A})$ & \multicolumn{2}{|c|}{49} & \multicolumn{2}{|c|}{33} \\
\hline \multicolumn{5}{|l|}{ Domestic deals } \\
\hline Mean of average scores & 2.58 & 2.51 & 2.49 & 2.56 \\
\hline$p$-value (1) & 0.27 & 0.38 & 0.01 & 0.21 \\
\hline p-value (2) & \multicolumn{2}{|c|}{0.26} & \multicolumn{2}{|c|}{0.29} \\
\hline Median of average scores & 2.65 & 2.50 & 2.49 & 2.48 \\
\hline Number of observations & \multicolumn{2}{|c|}{79} & \multicolumn{2}{|c|}{56} \\
\hline \# with aver(T)>aver(A) & \multicolumn{2}{|c|}{42} & \multicolumn{2}{|c|}{28} \\
\hline$\#$ with $\operatorname{aver}(T)=\operatorname{aver}(A)$ & \multicolumn{2}{|c|}{4} & \multicolumn{2}{|c|}{0} \\
\hline$\#$ with aver $(\mathrm{T})<\operatorname{aver}(\mathrm{A})$ & \multicolumn{2}{|c|}{33} & \multicolumn{2}{|c|}{28} \\
\hline \multicolumn{5}{|l|}{ Cross-border deals } \\
\hline Mean of average scores & 2.60 & 2.45 & 2.78 & 2.41 \\
\hline$p$-value (1) & 0.43 & 0.29 & 0.04 & 0.23 \\
\hline p-value (2) & \multicolumn{2}{|c|}{0.09} & \multicolumn{2}{|c|}{0.01} \\
\hline Median of average scores & 2.65 & 2.45 & 2.71 & 2.31 \\
\hline Number of observations & \multirow{2}{*}{\multicolumn{2}{|c|}{$\begin{array}{l}45 \\
28\end{array}$}} & \multicolumn{2}{|c|}{24} \\
\hline \# with aver(T)>aver(A) & & & & \\
\hline$\#$ with $\operatorname{aver}(T)=\operatorname{aver}(A)$ & \multicolumn{2}{|c|}{1} & \multicolumn{2}{|c|}{0} \\
\hline$\#$ with $\operatorname{aver}(\mathrm{T})<\operatorname{aver}(\mathrm{A})$ & \multicolumn{2}{|c|}{16} & & \\
\hline Non-announcement periods & & & & \\
\hline Mean of average scores & 2.6 & 2.49 & 2.61 & 2.49 \\
\hline Median of average scores & 2.6 & 2.49 & 2.58 & 2.44 \\
\hline Number of observations & 8026 & 11383 & 5053 & 7176 \\
\hline
\end{tabular}

(1) Null hypothesis: the mean of average scores is equal to the mean of average scores in non-announcement periods.

(2) Null hypothesis: equality of means of average scores for the sets of targets and acquirers firms. 


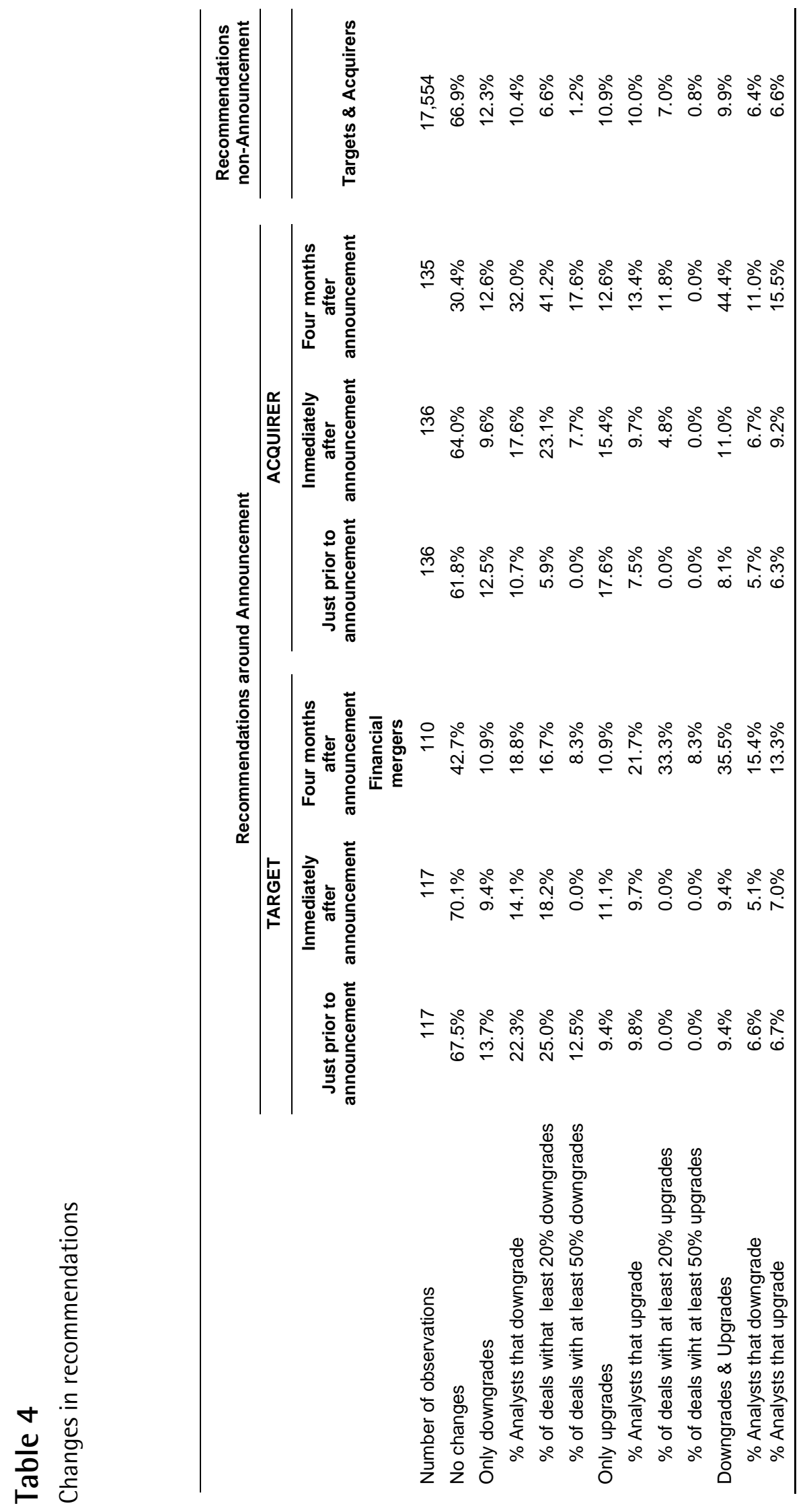




\section{Table 5}

Share of Competitors with Positive Excess Returns

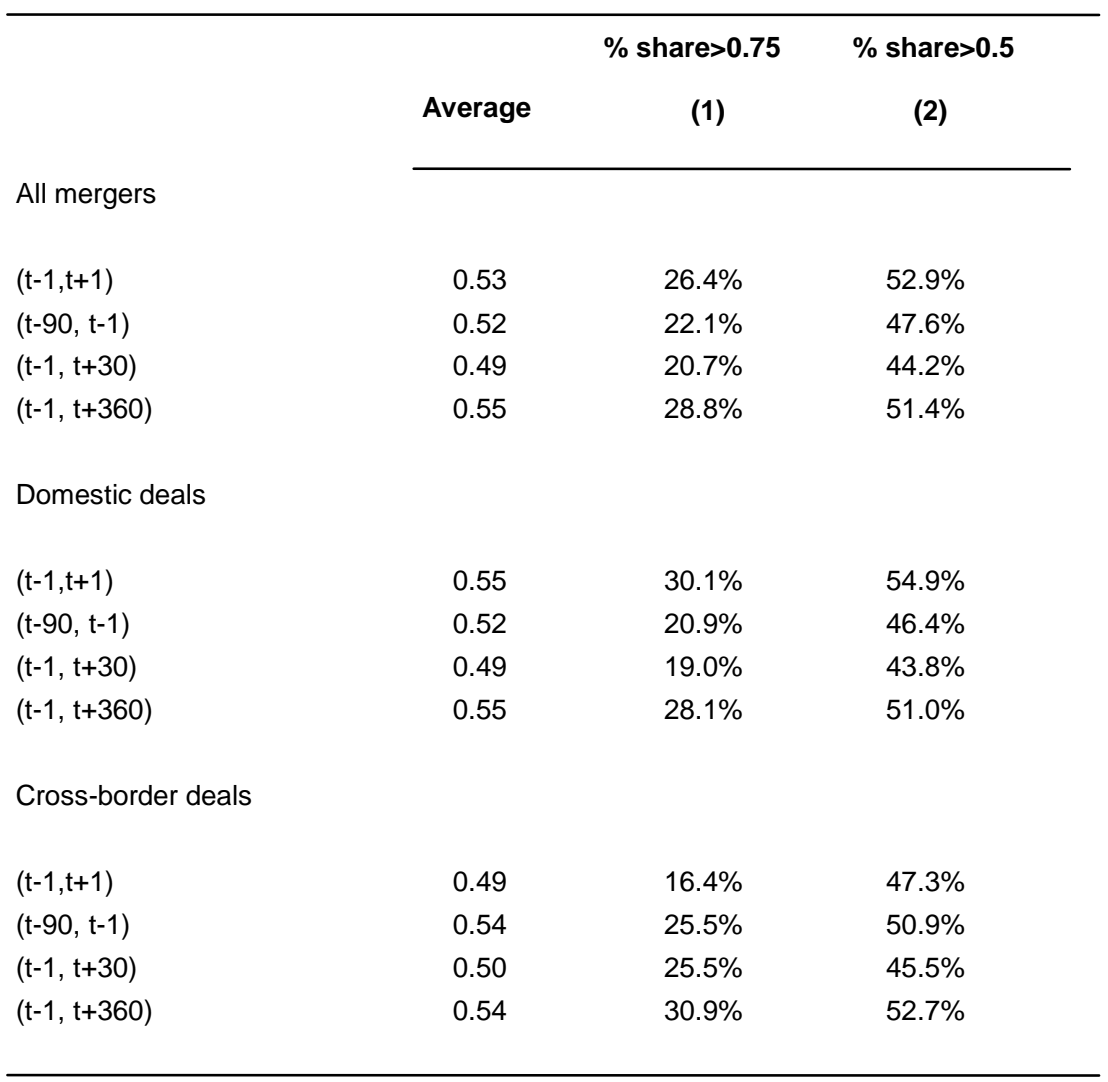

(1) Fraction of deals in which at least $75 \%$ of the rivals display abnormal positive returns.

(2) Fraction of deals in which at least $50 \%$ of the rivals display abnormal positive returns. 


\section{Table 6}

\section{Regression Analysis of Excess Returns}

The dependent variable are estimated excess returns around the announcement of the transaction relative to the performance of the national financial market index, over the window in days indicated in the top of the column. DOMESTIC is a dummy that takes the value 1 if the transaction involves two companies of the same country. BANKS is a dummy that takes the value 1 if the transaction involves two banks. RSIZE is defined as: ((tmv/(tmv+amv)-0.5 $)^{\star *} 2$ ) where tmv and amv denote the market capitalisation of the target and acquiring companies. SMALLDEAL (LARGEDEAL) is a dummy that take the value of 1 if the joint market capitalization of the involved companies is in the first(fourth) quartile of the distribution. RIVALS_ER is the average excess returns of the set of potential competitors and DOM_RIV is the interaction of RIVALS_ER and DOMESTIC.

\begin{tabular}{|c|c|c|c|c|c|c|c|c|}
\hline Event Window & $\begin{array}{c}(1) \\
(t-90, t-1)\end{array}$ & $\begin{array}{c}(2) \\
(t-1, t+1) \\
\end{array}$ & $\begin{array}{c}(3) \\
(t-1, t+30)\end{array}$ & $\begin{array}{c}(4) \\
(t-1, t+360) \\
\end{array}$ & $\begin{array}{c}(5) \\
(t-90, t-1) \\
\end{array}$ & $\begin{array}{c}(6) \\
(t-1, t+1)\end{array}$ & $\begin{array}{c}(7) \\
(\mathrm{t}-1, \mathrm{t}+30)\end{array}$ & $\begin{array}{c}(8) \\
(t-1, t+360)\end{array}$ \\
\hline \multicolumn{9}{|c|}{ Targets } \\
\hline DOMESTIC & 0.037 & -0.013 & 0.008 & 0.136 & 0.039 & -0.013 & 0.008 & 0.115 \\
\hline BANKS & -0.045 & 0.024 & 0.012 & 0.034 & -0.045 & 0.024 & 0.012 & 0.044 \\
\hline$R S I Z E$ & -0.107 & $0.332^{\star \star}$ & $0.328^{\star *}$ & 0.547 & -0.112 & $0.332^{\star *}$ & $0.343^{\star *}$ & 0.46 \\
\hline SMALLDEAL & -0.054 & 0.021 & 0.011 & -0.076 & -0.053 & 0.021 & 0.010 & -0.06 \\
\hline$\angle A R G E D E A L$ & 0.038 & $-0.042^{*}$ & -0.013 & 0.046 & 0.041 & $-0.042^{*}$ & -0.015 & 0.051 \\
\hline$R I V A L S \_E R$ & $0.581^{* * *}$ & 0.072 & $0.483^{* * *}$ & $0.582^{* * *}$ & $0.673^{* * *}$ & 0.044 & $0.827^{\star * *}$ & -0.118 \\
\hline DOM_RIV & & & & & -0.108 & 0.028 & -0.389 & $0.867^{* *}$ \\
\hline INTERCEPT & 0.046 & -0.004 & -0.006 & -0.157 & 0.044 & -0.004 & -0.007 & -0.14 \\
\hline Observations & 187 & 187 & 187 & 180 & 187 & 187 & 187 & 180 \\
\hline R-squared & 0.132 & 0.109 & 0.133 & 0.131 & 0.133 & 0.109 & 0.139 & 0.167 \\
\hline RMSE & 0.223 & 0.119 & 0.145 & 0.443 & 0.224 & 0.119 & 0.144 & 0.435 \\
\hline \multicolumn{9}{|c|}{ Acquirers } \\
\hline DOMESTIC & 0.009 & 0.000 & -0.013 & $0.134^{\star *}$ & 0.008 & 0.000 & -0.013 & $0.123^{*}$ \\
\hline BANKS & -0.008 & -0.012 & -0.001 & 0.084 & -0.008 & -0.011 & -0.001 & 0.089 \\
\hline RSIZE & 0.059 & 0.054 & 0.042 & $0.887^{\star *}$ & 0.062 & 0.054 & 0.028 & $0.840^{\star *}$ \\
\hline SMALLDEAL & 0.013 & -0.016 & 0.011 & -0.115 & 0.012 & -0.015 & 0.011 & -0.105 \\
\hline LARGEDEAL & $0.036^{*}$ & -0.007 & 0.009 & $0.118^{*}$ & 0.035 & -0.006 & 0.011 & $0.121^{*}$ \\
\hline$R I V A L S \_E R$ & $0.541^{* * *}$ & 0.020 & $0.243^{*}$ & $0.686^{* * *}$ & $0.490^{* * *}$ & -0.264 & -0.085 & $0.306^{*}$ \\
\hline DOM_RIV & & & & & 0.059 & 0.289 & 0.371 & $0.471^{\star *}$ \\
\hline INTERCEPT & 0.020 & 0.014 & 0.014 & -0.015 & 0.021 & 0.013 & 0.015 & -0.006 \\
\hline Observations & 187 & 187 & 187 & 180 & 187 & 187 & 187 & 180 \\
\hline R-squared & 0.208 & 0.079 & 0.091 & 0.218 & 0.208 & 0.081 & 0.101 & 0.228 \\
\hline RMSE & 0.154 & 0.054 & 0.105 & 0.420 & 0.154 & 0.054 & 0.105 & 0.418 \\
\hline
\end{tabular}

Year dummies not reported

${ }^{*}$ significant at $10 \% ;{ }^{* *}$ significant at $5 \% ;{ }^{* * *}$ significant at $1 \%$ 